University of Nebraska - Lincoln

DigitalCommons@University of Nebraska - Lincoln

Community and Regional Planning Program:

Faculty Scholarly and Creative Activity

Community and Regional Planning Program

$7-2020$

\title{
Using the electromagnetic induction survey method to examine the depth to clay soil layer (Bt horizon) in playa wetlands
}

Yuan Xue

Zhenghong Tang

Qiao Hu

Jeff Drahota

Follow this and additional works at: https://digitalcommons.unl.edu/arch_crp_facultyschol

Part of the Hydrology Commons, and the Urban, Community and Regional Planning Commons

This Article is brought to you for free and open access by the Community and Regional Planning Program at DigitalCommons@University of Nebraska - Lincoln. It has been accepted for inclusion in Community and Regional Planning Program: Faculty Scholarly and Creative Activity by an authorized administrator of DigitalCommons@University of Nebraska - Lincoln. 


\title{
Using the electromagnetic induction survey method to examine the depth to clay soil layer (Bt horizon) in playa wetlands
}

\author{
Yuan Xue ${ }^{1} \cdot$ Zhenghong Tang $^{1} \cdot$ Qiao Hu ${ }^{1}$. Jeff Drahota ${ }^{2}$ \\ Received: 4 September 2018 / Accepted: 26 June 2019 / Published online: 8 July 2019 \\ (C) Springer-Verlag GmbH Germany, part of Springer Nature 2019
}

\begin{abstract}
Purpose Sediment accumulation has been and continues to be a significant threat to the integrity of the playa wetland ecosystem. The purpose of this study was to determine the vertical depth to the clay soil layer (Bt horizon) and thus to calculate the thickness of sediments accumulated in playa wetlands.

Materials and methods This study used the electromagnetic induction (EMI) survey method, specifically EM38-MK2 equipment, to measure the vertical depth to the clay soil layer at the publicly managed wetlands in the Rainwater Basin, Nebraska, USA.

Results and discussion The results indicated that the depth to the clay soil layer ranges from 21 to $78 \mathrm{~cm}(n=279)$ with a mean sediment thickness of $39 \mathrm{~cm}$. The annual sediment deposition rate since human settlement in the $1860 \mathrm{~s}$ was calculated to be $0.26 \mathrm{~cm} \mathrm{year}^{-1}$. The results provided science-based data to support future wetland restoration planning and the development of decision support tools that prioritize conservation delivery efforts.

Conclusions Our research confirmed that the EMI technique is effective and efficient at determining the depth to the Bt horizon for playa wetlands. Additionally, these results supported previous studies and continue to indicate that a large amount of sediment has accrued in these playa wetlands within the Rainwater Basin area since settlement. Wetland restoration ecologists can use this information to prioritize future wetland restoration work that intends to remove culturally accumulated sediments above the clay soil layer. These findings provided a contemporary summary of wetland soil profile information that is typically used to develop restoration plans. This research also filled the critical knowledge gap about the thickness of the upper soils and the depth to Bt in publicly managed wetlands.
\end{abstract}

Keywords Bthorizon $\cdot$ Electromagnetic induction (EMI) survey $\cdot$ Playa wetlands $\cdot$ Sediment

\section{Introduction}

\subsection{Importance of sediment issues for playa wetlands}

Playa wetlands are nearly circular, shallow depressions located in semi-arid areas and are predominately formed by aeolian processes (Smith 2003). Playas are found in the lowest areas within closed watersheds and have a well-defined clay soil

Responsible editor: Geraldene Wharton

Zhenghong Tang

ztang2@unl.edu

1 Community and Regional Planning Program, University of Nebraska-Lincoln, Lincoln, NE 68588, USA

2 U.S. Fish and Wildlife Service, Rainwater Basin Wetland Management District, Funk, NE 68940, USA layer (Bt horizon, also called the clay pan) just beneath the wetland surface (LaGrange et al. 2011; NRCS 2015). This Bt layer impedes downward water movement and supports ponded conditions within these hydric soil footprints when adequate runoff occurs. Soils within the upper profile have more organic matter and larger particle sizes (NRCS 2015) that increase water storage capacity within these layers rather than facilitating surface water ponding. Therefore, the depth to Bt or the thickness of the soil layers above the Bt can significantly affect wetland function, integrity, and sustainability for playa wetlands (Tang et al. 2015a).

The Rainwater Basin region is located in the narrow corridor of the Central Flyway and plays a significant role as stopover habitat for waterfowl and shorebirds during spring migration (Gersib et al. 1992; Brennan et al. 2005). When ponding occurs, these wetlands provide abundant wetland-derived seed resources that support the North American Waterfowl Management Plan objectives (Drahota and Reichart 2015). 
Many of these playa wetlands have been protected as waterfowl production areas (WPAs) and wildlife management areas (WMAs) that provide habitats for millions of waterfowl and other waterbirds including the threatened piping plover (Charadrius melodus) and bald eagle (Haliaeetus leucocephalus), and the federally endangered whooping crane (Grus americana) (LaGrange 2005; USFWS 2007).

Sediment accumulation has been and continues to be a significant threat to the integrity of the playa wetland ecosystem (Haukos and Smith 2003; Tsai et al. 2010; Daniel et al. 2015; Tang et al. 2015a, b). LaGrange et al. (2011) highlighted the consequences of sediment accumulation on playa wetlands, specifically on hydrological function, water quality, plant community structure, and impacts to invertebrate and vertebrate populations. Sediment within any wetland footprint can increase the water storage capacity within the soil profile due to the interstitial pore space in the unconsolidated sediment, and therefore can reduce the frequency and duration of surface water expression (Tsai et al. 2010; Tang et al. 2015b). The surface runoff spates transport sediment from tilled uplands down slope to playa wetlands causing rapid accumulation compared with pre-settlement conditions when grassed uplands limited soil movement. Thus, the water storage capacity of playa wetlands has declined, and wetland function has been severely altered (Goldsborough and Crumpton 1998; O'Connell et al. 2013). As the accumulation of sediment increases in playa wetlands, the water storage capacity within the soils above the clay pan increases causing less frequent surface ponding, declines in water depth, and shorter hydroperiods (Tang et al. 2018). Although short-term gains in the ponded area may be noted after significant runoff events, the hydroperiod will be shorter and the overall ponded area will be smaller during average climate conditions given excessive sediment accumulation (Cariveau et al. 2011; Uden et al. 2015). Furthermore, the loss of water storage volume resulting from aggradation will not only provide favorable conditions for invasive plant species (Galatowitsch et al. 1999; Smith and Haukos 2002) but also make them more vulnerable to agricultural conversions (Tsai et al. 2010; Tang et al. 2015b). Since playa wetlands are extremely sensitive to sediment accumulation, the thickness of accumulated soils above the clay layer is an important measure used in wetland restoration planning. Therefore, this research focused on determining the thickness of soils accumulated above the Bt horizon on publicly owned playa wetlands. This research was designed to provide a scientific inventory of the current conditions that restoration ecologists can use to plan and prioritize wetland restoration decisions, particularly for sediment removal projects.

\subsection{Culturally accelerated sediment on playa wetlands}

Culturally accelerated sedimentation occurs when land management practices accelerate the deposition of soils into playa wetlands breaking the balance of input and output of sediment in the natural sedimentation process (LaGrange et al. 2011). The culturally accelerated sediment from the cropland portion of the watershed has become the primary input into playa wetlands (LaGrange et al. 2011). Figure 1 illustrates the juxtaposition of rapid soil accumulation above the clay soil layer (the Bt horizon) (modified from Schafersman 2011).

Before European settlement in the Great Plains, playa wetlands occurred in a landscape with minimal anthropogenic disturbances, and persisted through natural disturbances such as drought and deluge events, fire, and grazing. All of these disturbances facilitated some soil deposition events along with deflation events that frequently removed deposited soils. In the natural cycle of soil erosion, transport, and deposition into playas, the amount of sediment moving into wetlands would be offset by the amount of sediment moving out of playa wetlands via wind deflation. Therefore, the inputs and outputs of sediment, to some degree, were considered to be in balance (Gill 1996; Luo et al. 1997, 1999; Smith 2003; LaGrange et al. 2011).

However, from the mid to late 1800s, the European settlement of the central USA began to occur after the arrival of railroads to the Great Plains (LaGrange et al. 2011; Tang et al. 2015a). The Homestead Act passed by Congress in 1862 required claim holders to build a certain size dwelling, and improve the land by growing crops within 5 years of the homestead application (Potter and Schamel 1997). This facilitated rapid conversion of grassland into cropland in the late $1800 \mathrm{~s}$ (Layton et al. 1927), and most of the landscape was converted to croplands in south-central Nebraska. These tilled lands were exposed to wind and water erosion for a good portion of the year. As a result, an increase in the rate and amount of eroded topsoil was transported and deposited into depressional playa wetlands.

The accumulated sediments are functioning as a subsurface storage area and can store a considerable amount of water. The capacity of playa wetlands has been reduced by excessive sediment inputs. In fact, many only pond water after a considerable amount of precipitation has occurred in a short amount of time because of excessive sediment accumulation. Consequently, playas with high amounts of sediment accumulation require larger runoff events to facilitate ponding (Cariveau et al. 2011). Therefore, contemporary hydroperiods are significantly different from the pre-settlement era. Culturally accelerated sedimentation expedites successional transitions from wetland habitat to mesic or even upland habitat, and without appropriate removal of excessive sediment inputs, many playas will continue to be dysfunctional (LaGrange et al. 2011; Tang et al. 2016, 2018). Mapping the shallow soil vertical profile is critical in understanding the pattern, distribution, and trend of sediment accumulation in playa wetlands. Thus, this study focused on determining the depth to Bt that is frequently used as a benchmark depth for designing and implementing wetland restoration projects. 


\subsection{Approaches for sediment estimation}

Recent research has greatly improved our understanding of playa sediment issues in the Rainwater Basin (Renard et al. 1997; Beas et al. 2013a; Daniel et al. 2015, 2017; Tang et al. 2015b). Although the soil erosion models can be used to estimate soil erosion rates at the landscape level, the actual sediment deposition rate is subject to the transport capacity at the watershed scale (Renard et al. 1997). Cropland area at the watershed scale can have a significant influence on runoff rates, sedimentation rates, and declines in water storage capacity in playas (Daniel et al. 2015). The contemporary inundation patterns of playa wetlands in the Rainwater Basin have been affected by excessive amounts of sediment deposited (Tang et al. 2015b). Recent studies also examined the effectiveness of sediment removal on playa wetland performance. Sediment removal has been linked to improvements in plant community characteristics (Beas et al. 2013a), and improvements in carbon and nitrogen storage in playa wetlands (Daniel et al. 2017). Yet, we still lack the ability to efficiently evaluate the depth to Bt that will help develop prioritization models to support conservation delivery efforts, particularly for sediment removal projects.

Wetland researchers, managers, and restoration ecologists still rely heavily on traditional field drilling or sampling techniques that allow the examination of wetland sediment profiles (Gleason and Euliss 1998; Olson and Jones 2001; Tang et al. 2015a). Traditional point measurement sampling techniques, such as soil coring, mechanical probes, and pit excavation, can provide soil profile information, but they are destructive, labor-intensive, and time-consuming. Moreover, these traditional soil survey tools not only provide partial or limited information but also provide an incomplete characterization of the subsurface profile at a localized level that is helpful for developing wetland restoration plans. Soil scientists must apply both visual and tactile observations to make interpretations based on inferences made across typically large and extensive areas using wide-ranging core samples (Sudduth et al. 1999). By increasing our ability to provide detailed site-specific soil profiles rapidly, we can describe the variability and dynamics soil moisture and clay content. Therefore, determining the depth to $\mathrm{Bt}$ is essential to defining the potential hydrologic impacts caused by accumulated sediment that ultimately support comprehensive wetland restoration designs.

\subsection{Electromagnetic induction technique in sediment research}

The electromagnetic induction (EMI) technique has been used to characterize the spatial variability of soil properties, such as clay content and soil salinity since the 1970s (de Jong et al. 1979; Williams and Baker 1982). EMI can measure the apparent soil electrical conductivity by inducing an electrical current in the soil (Saey et al. 2009), but has not been adequately tested for use in playa wetlands. The EMI approach is non-invasive, and it can provide immediate results. Therefore, it can be used to develop the inventory of lateral changes in soil properties underlying soil surfaces (Saey et al. 2009). The measurement depth is primarily determined by the coil

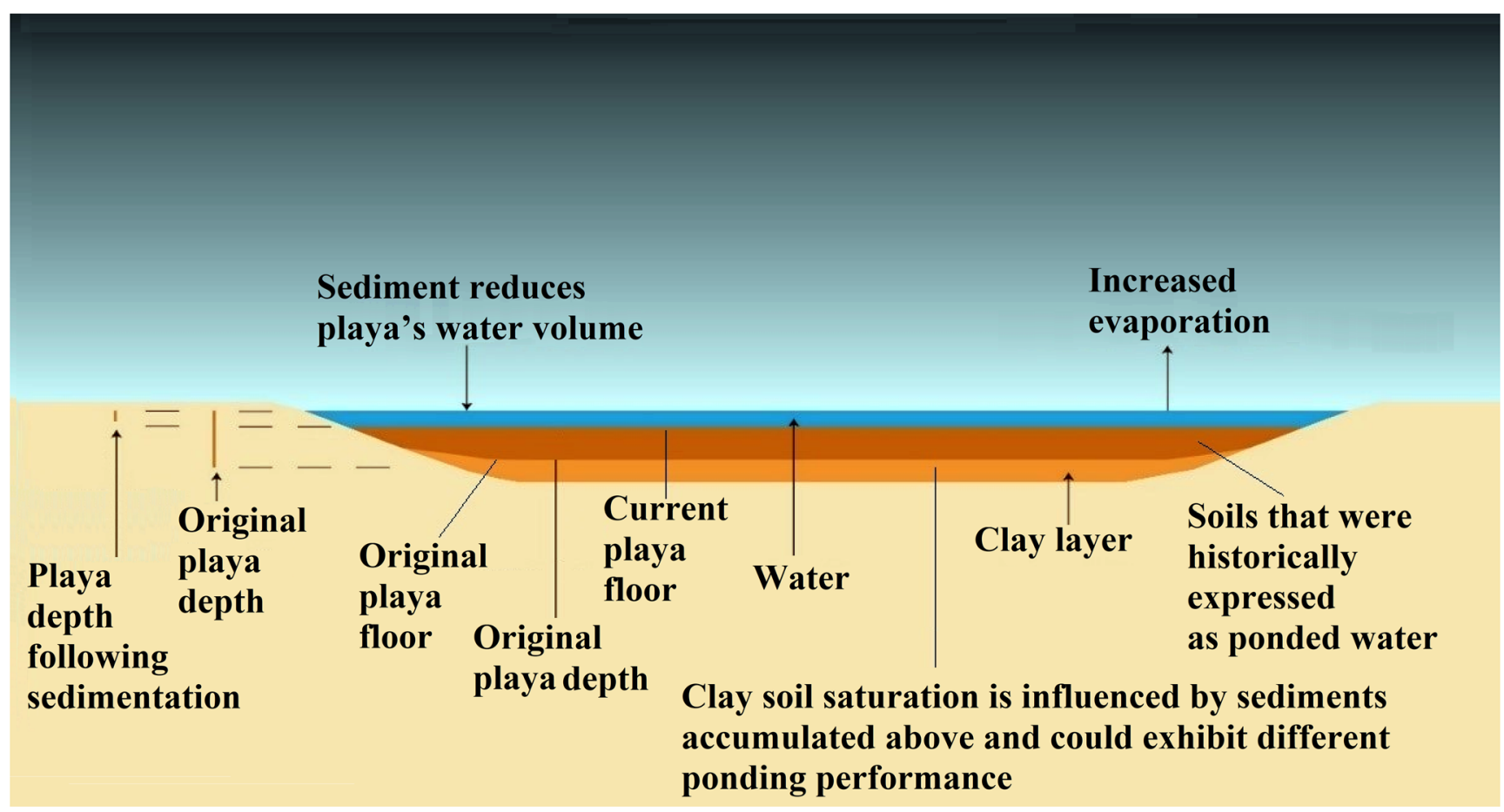

Fig. 1 Illustration of culturally accelerated sediment in playa wetlands (modified from Schafersman 2011). The darker orange area indicates new soils that may have been deposited since settlement and are filling the area with soil rather than ponded water 
orientation, coil spacing, frequency of the induced current, and the height of the EMI instrument above the ground (Gebbers et al. 2007; Saey et al. 2009). Electrical conductivity in the soil is determined from the combination of physical and chemical soil properties (Corwin and Lesch 2005) such as soil porosity, soil salinity, clay content, water content, concentration of dissolved electrolytes in the soil solution, cation exchange capacity, composition of colloids, and temperature (Sundberg 1932; McNeill 1980; Rhoades et al. 1989; Sudduth et al. 1999; Saey et al. 2009; Sudduth et al. 2010; Herrero and Castaneda 2015). In principle, the apparent electrical conductivity at different depths can be obtained from the measures at different heights above the soil surface (Borchers et al. 1997). Soil electrical conductivity rises when soil conditions change such as increases in water content or percent clay (Freeland 1989).

The EMI techniques have been verified as useful tools to distinguish soil types and properties (Ammons et al. 1989; Heil and Schmidhalter 2012; White et al. 2012; Doolittle and Brevik 2014). Sudduth et al. (1995) used the EMI to examine the depths to clay pan, and Doolittle et al. (1995) used it to determine the thickness of floodplain splay deposits. In addition, EMI can effectively distinguish and map the soil conditions by detecting soil water content (Hezarjaribi and Sourell 2007; Huth and Poulton 2007) and soil salinity (Cook and Walker 1992; Yao et al. 2012; Herrero and Castaneda 2015). Doolittle et al. (1994) observed high correlations between the observed depth to claypan and the response of the EMI measurement in central Missouri. Sudduth et al. (1995) found high statistical agreement between the soil probe depth and the EMI estimated depth. Kitchen et al. (1996) used the EMI technique to estimate sand deposition by detecting the conductivity between sand and other soils. Boettinger et al. (1997) evaluated the soil depths for 216 soil sampling points at the $0-150-\mathrm{cm}$ level and concluded that EMI is useful tool "for nondestructively assessing soil depth to a cemented subsoil horizon quickly and inexpensively." Bork et al. (1998) evaluated the two EMI meters (EM38 and EM31 models) for non-destructively assessing soil depth to bedrock in grazing lands with different vegetation compositions. Freeland et al. (2001) pointed out the EMI technique is particularly suitable for the areas where subsurface properties are reasonably homogeneous.

The EMI response can clearly reflect the variations in properties (e.g., clay, water, or salt content) particularly when they dominate over other properties (Cook and Walker 1992; Freeland et al. 2001). The Natural Resource Conservation Service (NRCS 2002) found that the EMI method could accurately mirror soil survey maps and determined that the higher conductivity readings at greater soil depths was attributed to the increased clay and moisture contents of each soil horizon. This led them to recommend the EMI technique as a reliable method for soil survey verification and wetland delineation within the
Platte River area of Nebraska (NRCS 2002). Saey et al. (2008) used the EMI technique (EM38DD model) to map the depth to the Tertiary clay substrate and reached a high correlation coefficient with independent observations. Saey et al. (2009) reconstructed the interface depth between the Quaternary loess and the Tertiary clay. Doolittle and Brevik (2014) summarized the EMI technique as a rapid, non-destructive, cost-effective approach to measure the spatial variability of soil properties. Based on the established literature, this study adopted the EMI technique and further expanded its application to identify the upper compacted layer of a playa wetland for precise wetland evaluations.

\subsection{Research objectives}

The overall goal of this research was to test the EMI survey technique to determine the depth to Bt in publicly managed wetlands in the Rainwater Basin, Nebraska, USA. We evaluated the EMI survey technique to determine if it can efficiently establish a depth to Bt and thus estimate the thickness of accumulated sediments in wetlands. This study was designed to fill a critical knowledge gap about the vertical profile of playa wetlands that can help to determine future wetland restoration priorities on public properties.

\section{Methods}

\subsection{Study area}

The location of the Rainwater Basin is shown in Fig. 2. The Rainwater Basin region encompasses 15,907 $\mathrm{km}^{2}$ including all or parts of 21 counties on the Loess Plains of south-central Nebraska (LaGrange 2005). The Rainwater Basin consists of natural wind-formed wetland depressions that tend to have a northeast to southwest orientation (Kuzila and Lewis 1993). The landscape of the playa complex features flat to gently rolling plains which are formed by deep deposits of windblown loess, and the size of wetlands range from less than $4,000 \mathrm{~m}^{2}$ (approximately 1 acre) to over $4.0 \mathrm{~km}^{2}$ (approximately 1,000 acres). Each playa is identified by a characteristic hydric soil that typically has prolonged ponding during the growing season (Allen et al. 1972; Beas et al. 2013a). Our study sites in the Rainwater Basin comprise 93 publicly managed wetland watersheds including 35 Wildlife Management Areas (WMAs) managed by the Nebraska Game and Parks Commission and 58 Waterfowl Production Areas (WPAs) managed by US Fish and Wildlife Service.

\subsection{Equipment and software}

The EMI instrument used in this study is the EM38-MK2 manufactured by Geonics Limited, Mississauga, Ontario, 
Canada. The EM38-MK2 equipment includes a lightweight bar approximately $1 \mathrm{~m}$ in length that contains a transmitter and two receiver coils (Grisso et al. 2009). It is designed to be held by hand and take stationary electrical conductivity readings (Sudduth et al. 2010), and it includes a digital readout of electrical conductivity in millisiemens $(\mathrm{mS})$ per meter with calibration controls. Collected data can be logged into a DAS 70-AR Data Acquisition System embedded in an Archer 2 Field Computer, connected by either Bluetooth wireless technology or an RS-232 serial cable.

We used the differential global positioning system receiver which has a 1-2-m accuracy to document each sampling point. At each sample location, EM38-MK2 was used to measure changes in the magnetic field between a transmitting and receiving coil. The device operated at a frequency of $14.5 \mathrm{kHz}$ and provides measurements of ground apparent electrical conductivity (Quad-Phase). Two transmitter receiver coil separations occurred at $1.0 \mathrm{~m}$ and $0.5 \mathrm{~m}$ with 3 effective depth ranges at $0.75 \mathrm{~m}$ and $1.5 \mathrm{~m}$ in vertical dipole mode, and two ranged at $0.38 \mathrm{~m}$ and $0.75 \mathrm{~m}$ in horizontal dipole mode. In this study, the instrument was operated only in the vertical dipole mode with coil separation at $1.0 \mathrm{~m}$ to reach the effective signal detection depth of approximately $1.5 \mathrm{~m}$. After the field data collection, the Interpex Limited 1X1Dv3 inversion software (Interpex. com at Golden, Colorado, USA) was used to generate one- dimensional conductivity versus depth profiles. The depth to Bt was derived from the inversion results.

\subsection{Data source for soil series}

The Soil Survey Geographic (SSURGO) database (NRCS 2015) was produced by the US Department of Agriculture's Natural Resources Conservation Service. We used the SSURGO data to determine the locations of hydric soil footprints and the soil classifications for each public wetland (Tang et al. 2015b). The primary wetland soil series found on public lands include Massie, Scott, Fillmore, Butler, and Rusco. According to the soil classifications, Massie series consists of very poorly and deep drained clay pan soil that formed in loess modified by water (NRCS 2015). Massie soils, when present, are typically in the lowest portions of hydric footprints and are often the wettest areas. Massie soils generally tend to function as semi-permanently ponded wetland habitat (Cowardin et al. 1979). The Scott soil series consists of very deep and poorly drained soils (NRCS 2015). Scott soils occur in the lower elevations of these depressional wetlands (NRCS 2015), but are above the Massie soil areas when present. Scott soils normally provide seasonal ponded habitat (Cowardin et al. 1979). Other soil types, such as Butlers, Fillmore, and Rusco soils, tend to be temporarily

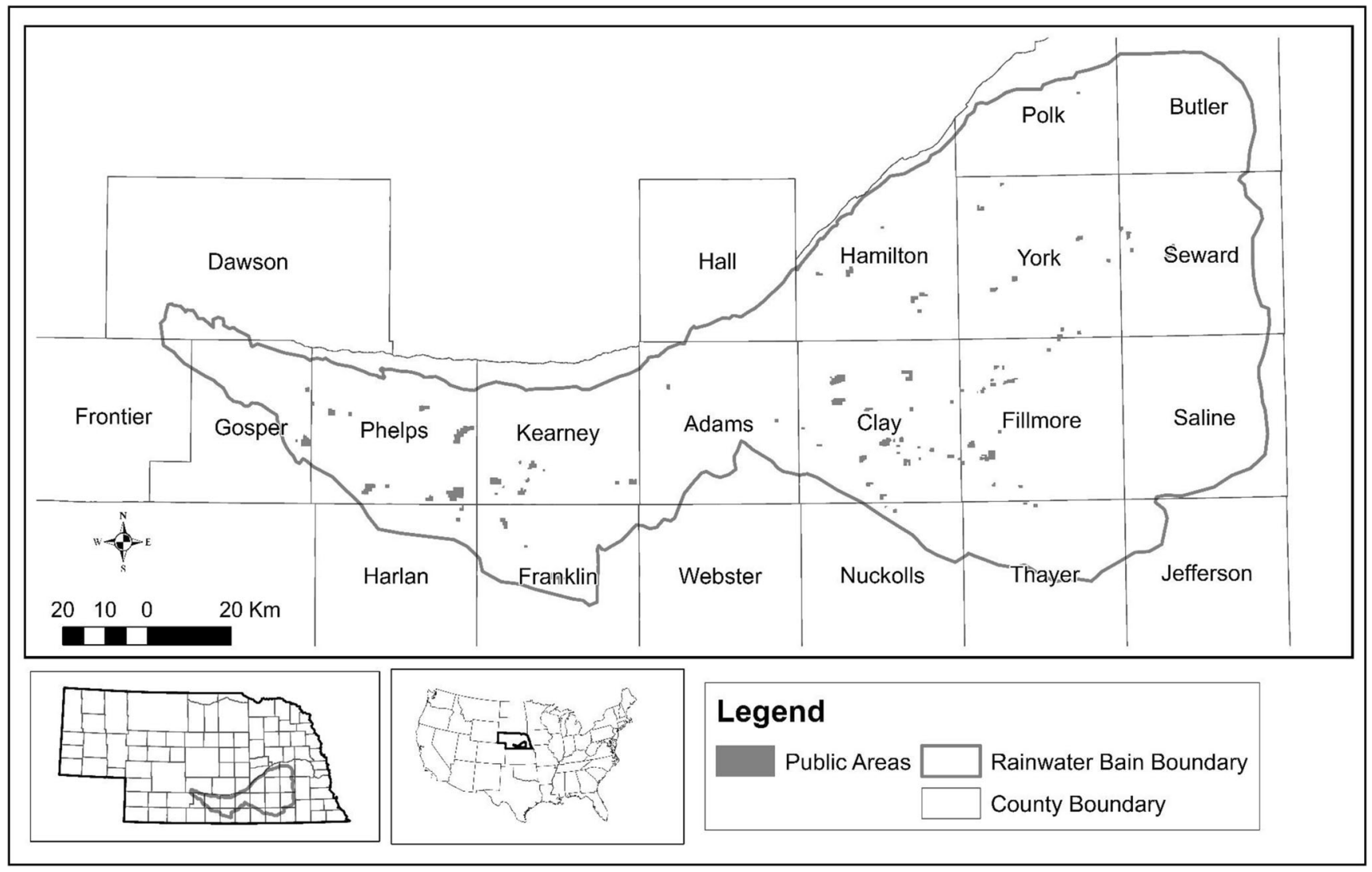

Fig. 2 Location of the publicly managed wetlands in the Rainwater Basin 
ponded (Cowardin et al. 1979). Fillmore soils consist of somewhat poorly and very deep drained soils in shallow closed depressions or basins of stream terraces and uplands (NRCS 2015). The Fillmore series is normally positioned at lower elevations than the Butler series, but are higher than the Massie series when they occur within the same hydrologic soil footprint. Butler soils are somewhat poorly and very well drained soils that formed in loess or mixed loess (NRCS 2015). Butler soils are typically positions on flat or shallow depressions on loess uplands and high stream terraces (NRCS 2015), and are normally positioned higher than Fillmore and Scott soils in the landscape when they occur within the same hydric soil footprint. For example, at the Jones WPA watershed scale (as illustrated in the Fig. 3), the Holdrege soils dominated for $84.0 \%$ of the watershed areas. Holdrege soils are mainly distributed in uplands within the watershed. Each of the Fillmore silt loam soils and Scott silt loam soils occupy $4.9 \%$ of watershed while other soil types (Butler silt loam, Crete silt loam, Detroit silt loam, Uly and Coly silt loams) account for $6.2 \%$ of watershed areas.

\subsection{Data collection and analysis methods}

At each wetland footprint, we determined hydrologic routes, delivery points, and obvious silt plumes to minimize the possible influence from point-source deposition. Then, we identified areas that were likely to have uniform soil deposition within the lowest area of each hydric soil footprint, and then in an area that was easy to access. After these areas were located, we randomly positioned sampling areas. Then we cleared vegetation to create a bare soil area and collected three field measurements in the cleared area. The sampling strategy focused on the soils at the lowest elevation within each hydric soil footprint on public lands. Therefore, the data were collected with the following priority: (1) Massie series, (2) Scott series, (3) Fillmore series, and then the other soils. On the SSURGO soil map, these soil series are horizontally distributed on landscape, yet in the field these soil series represent different elevations at the watershed scale. We did remove dead plant material and live vegetation from the sample locations to ensure the ground conductivity meter was not influenced by electrical insulting material on the soil surface. Additionally, the soil surface was leveled off to create a relatively accurate reference plane when measuring the height above the referenced soil surface. Then, EM38-MK2 was deployed to collect conductivity values in both east-west and north-south directions in vertical mode with the transmitter receiver coil separation at $1.0 \mathrm{~m}$. At the sample point, the instrument was held above the reference plane at a height of $0-150 \mathrm{~cm}$, in $10-\mathrm{cm}$ increments, and it stayed at each elevated increment for approximately $1 \mathrm{~min}$ to allow the unit to average the readings at each height increment.

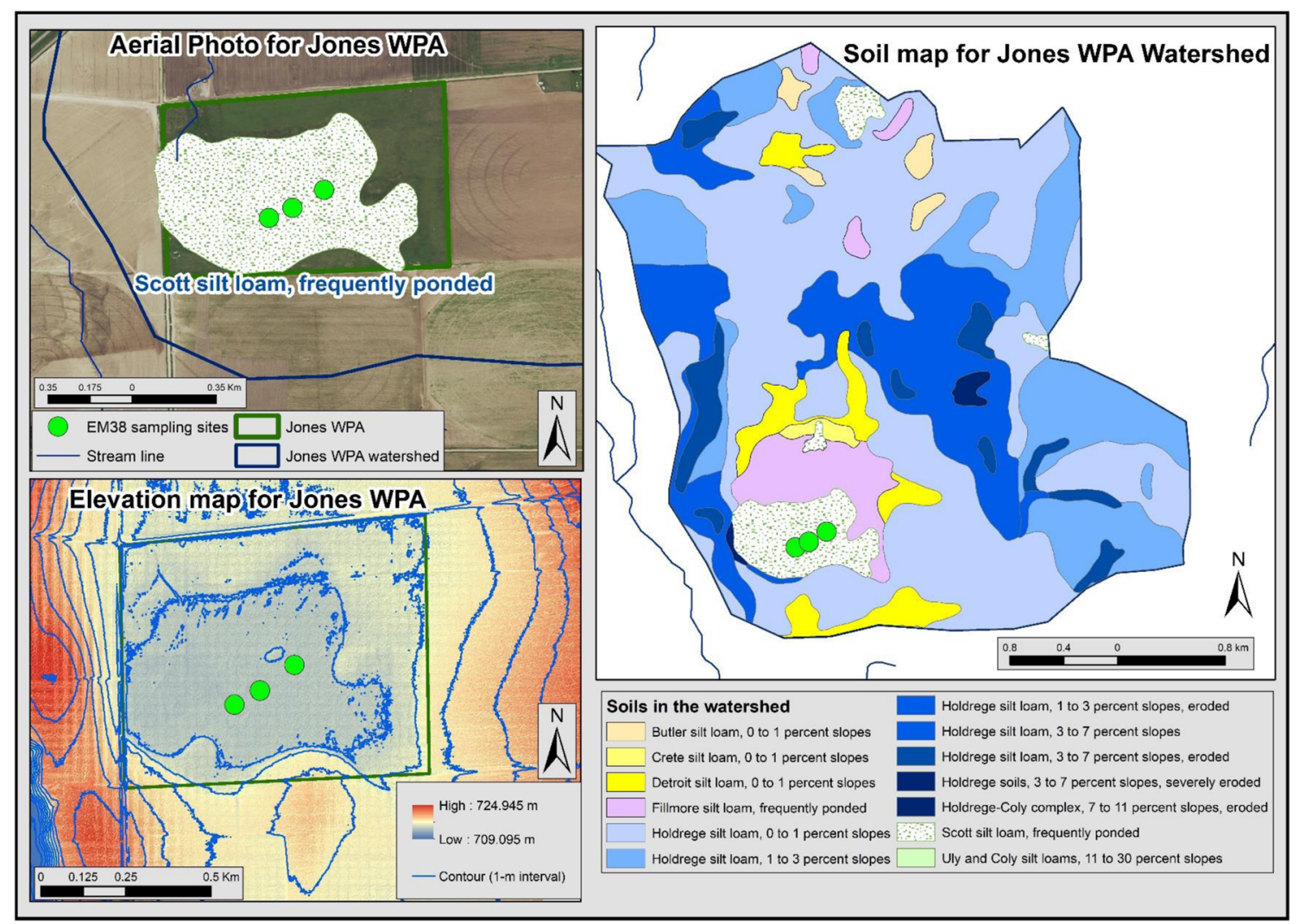

Fig. 3 Data collection and soil core sites in Jones WPA hydric soil footprint (left upper). The representative watershed is outlined in blue (right upper) 
The EMI data were analyzed using the Interpex Limited 1X1Dv3 software (Golden, Colorado, USA). The Occam inversion smooth method was used to generate one-dimensional conductivity depth profiles for each replicate at each sample site. The data were visualized using 15-20 layers, depending on the best-fit pattern that minimizes the root mean square of the EMI conductivity value. After that, the multiple iteration inversion was used to analyze the equivalent layered pattern where only three split layers were displayed. Then, the equivalent layered pattern that best fits the conductivity value and the smoothing method were chosen to represent the vertical soil conductivity profile.

\section{Results}

\subsection{Results validation in two wetlands}

The EMI measurement results were validated with field survey data in two public wetlands. First, at Jones WPA in Phelps County, Nebraska, three soil cores were taken within the Scott soil series in 2012. The depth to Bt for those three cores were verified in the field by soil scientists (M. Kuzila and N. Dominy) and later quantified in the lab by visual observation by a University of Nebraska soil scientist (M. Kuzila). In this study, the data collection with EM38-MK2 was calibrated three times at each study wetland on August 16, 2016 (Fig. 3). The EMI sampling points were matched up with the soil cores points by using the same GPS coordinates. As illustrated in Fig. 4, these three split layers from top to bottom separately represent the sediment soil layer (includes the " $\mathrm{A}$ " and " $\mathrm{E}$ " horizons), the Bt horizon, and the subsoil layer underlying the clay pan. In these clay-pan depressional wetlands, the dominant factor causing the EMI measurement changes on the vertical sediment profile is the variations of soil types. Clay soil particles have a huge surface area to volume ratio; thus, it has a much higher exchange capacity than other soil types. Therefore, the reflection of the clay soil layer can appear much denser than the top layer of accumulated sediments. The first horizontal red line from the top surface is the marker to distinguish the accumulated soils above the Bt horizon. The inferred depth to Bt from the inversion results in Fig. 4 were $27 \mathrm{~cm}, 25 \mathrm{~cm}$, and $28 \mathrm{~cm}$ at site 1 , site 2, and site 3, respectively. The depths to the clay soil layer from the lab observations for the three sites were $25 \mathrm{~cm}, 20 \mathrm{~cm}$, and $25 \mathrm{~cm}$, respectively. The field observation photo is shown in Fig. 5. The soil scientists determined the depth to $\mathrm{Bt}$ was $25 \mathrm{~cm}$, indicating that the thickness of accumulated soils was also $25 \mathrm{~cm}$. This resulted in no significant difference between the two measurement strategies of soil core sampling and EMI measurements.

We further validated the utility of EMI method at the Kenesaw WPA in Adams County, Nebraska on September 6,2016 . Seven data collection sites were measured using the
EM38-MK2 equipment. The first four sampling points located in higher elevations within the wetland footprint that were land leveled prior to acquisition. The EMI equipment indicated a mean depth to Bt of $46 \mathrm{~cm}$ (range 38 to $53 \mathrm{~cm}$ ). Then, we sampled three points within an area near the lowest elevations of the wetland (the deepest areas were pits excavated in the 1970s so we did not sample within the lowest elevations). In this area, the mean depth to $\mathrm{Bt}$ was $29 \mathrm{~cm}$ (range was 24 $35 \mathrm{~cm}$ ). Interestingly, the soil core sampling in these same areas indicated that the depth to $\mathrm{Bt}$ was $45 \mathrm{~cm}$ and $30 \mathrm{~cm}$, respectively. The EMI measurements were essentially consistent with the mean depth to $\mathrm{Bt}$ at within these two areas within the wetland footprint. Therefore, these results indicate that the EMI can serve as a reliable alternative tool to effectively detect the depth to $\mathrm{Bt}$ in the playa wetlands.

\subsection{Depth to clay for all public wetlands}

We evaluated 93 publically managed wetlands by conducting 3 field measurements within each wetland footprint for a total of 279 measurements. We found that the mean depth to Bt for all 279 sampling points was $39 \mathrm{~cm}$ with a standard deviation of $11 \mathrm{~cm}$. There were large variations in depth to Bt across these wetlands that ranged from 21 to $78 \mathrm{~cm}$ (Fig. 6). Yet, we used all of the data to calculate a mean annual sediment deposition rate of $0.26 \mathrm{~cm}_{\text {year }}{ }^{-1}$ for all publicly managed wetlands with the assumption that rapid sedimentation has been occurring over the last 150 years given the increase in anthropogenic activities.

We found that a significant number of the wetlands had thick sediment accumulations above the Bt. Across all sample locations, the sediment thickness profiles at the 10th percentile, 25 th percentile, 50th percentile, and 75 th percentile reached $27 \mathrm{~cm}, 30 \mathrm{~cm}, 38 \mathrm{~cm}$, and $45 \mathrm{~cm}$, respectively.

We also calculated the mean values of the 3 sampling points in each wetland to ascertain the internal variations of the EMI measurements. Across all 93 wetlands, the mean was less than $6 \mathrm{~cm}$. These results indicated a high level of internal consistency of the EMI measurements in each site. But, even in one wetland area, the EMI measurements may still be varied by many possible external factors (e.g., micro-topographic condition, vegetation condition, drainage pattern, agricultural disturbance). In this study, only five sites, accounting for 5\% of the total 93 sites, had the internal variations larger than $11 \mathrm{~cm}$, which was the overall standard deviation for all 279 samples.

We summarized the mean value of the depth to $\mathrm{Bt}$ in both ownership categories (Fig. 7)-WMAs and WPAs. For the 105 sampling points in the 35 state-managed WMA wetlands, the depth to $\mathrm{Bt}$ ranged from 24 to $78 \mathrm{~cm}$. The mean thickness of accumulated soils above the Bt in these WMAs was $42 \mathrm{~cm}$ with a standard deviation of $12 \mathrm{~cm}$, and the maximum depth to Bt was $78 \mathrm{~cm}$ at Southeast Sacramento WMA. For the 174 


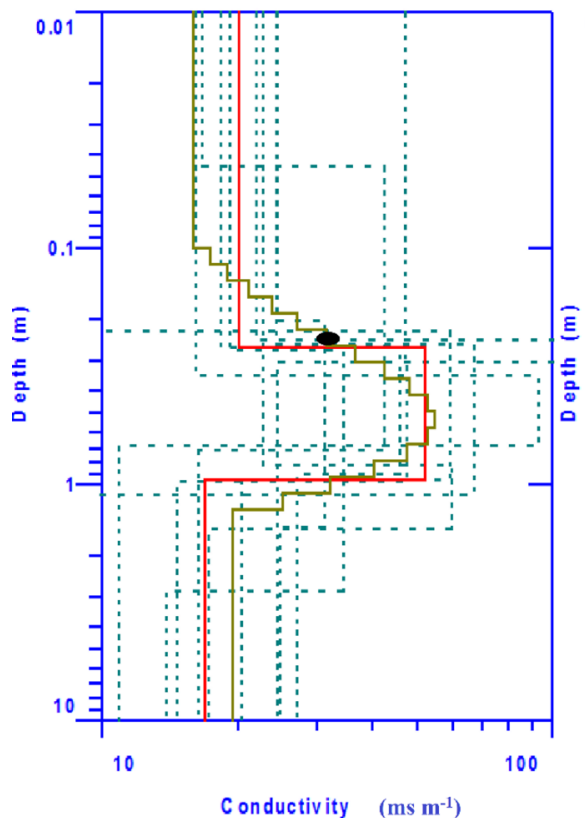

Jones WPA site 1

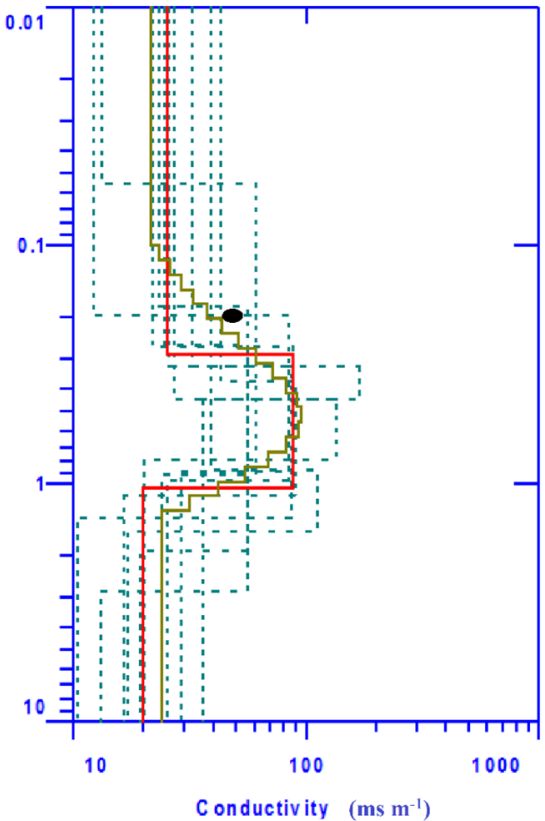

Jones WPA site 2

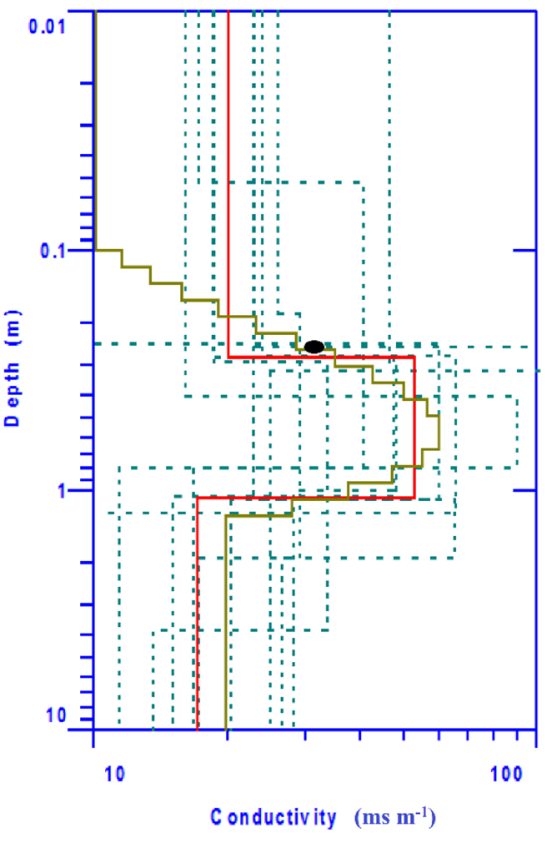

Jones WPA site 3
Fig. 4 Comparison of the EMI measurements and soil core samples at the three areas in Jones WPA (the top horizontal red line indicates the best-fit pattern from the Occam inversion smooth method based on the

sampling points within the 58 federally managed WPA wetlands, the depth to $\mathrm{Bt}$ ranged from 21 to $71 \mathrm{~cm}$. The mean thickness of accumulated soils above the $\mathrm{Bt}$ in these wetlands was $37 \mathrm{~cm}$ with a standard deviation of $9 \mathrm{~cm}$, and the maximum depth to Bt was $70 \mathrm{~cm}$ at Weseman WPA.

\subsection{Depth to clay within specific wetland soil series}

We determined the mean depth to Bt for each of the primary soil types within the lowest portion of the wetlands sampled (Fig. 8). For the 153 sampling points within the Massie soils, the $\mathrm{Bt}$ depth ranged from 23 to $78 \mathrm{~cm}$. The mean thickness of

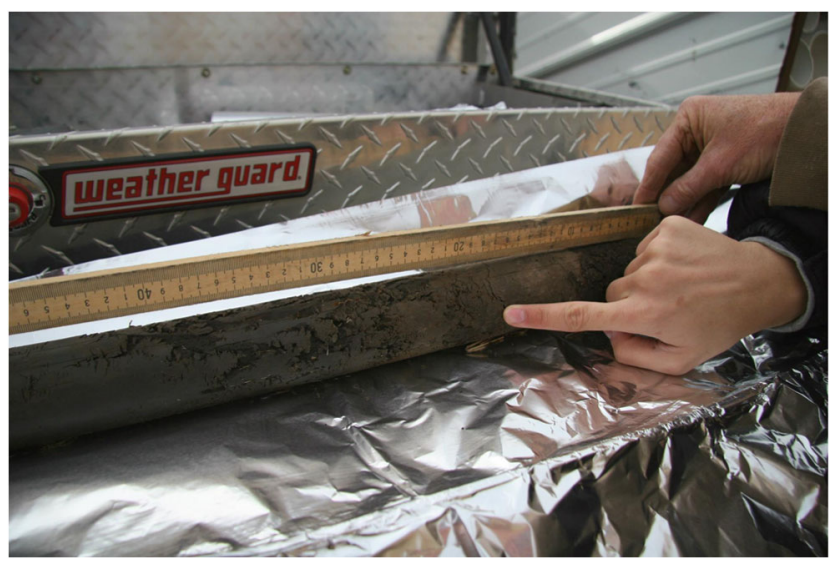

Fig. 5 A soil core from Jones WPA indicating $25 \mathrm{~cm}$ of sediment accumulation above the Bt horizon (darker soils deeper in the profile) electromagnetic conductivity. The black dot indicates the field observation result from the soil cores)

accumulated soils above the $\mathrm{Bt}$ in the Massie soils was $40 \mathrm{~cm}$ with a standard deviation of $11 \mathrm{~cm}$. In contrast, the $84 \mathrm{sam}$ pling points within the Scott soil areas had a range of depth from 24 to $62 \mathrm{~cm}$. The mean thickness of accumulated soils in the Scott soils was $38 \mathrm{~cm}$ with a standard deviation of $10 \mathrm{~cm}$. Similarly, for the 27 sampling points collected in the Fillmore soils, the depth to clay soil layer ranged from 24 to $66 \mathrm{~cm}$. The mean thickness of accumulated soils in the Fillmore soils was $37 \mathrm{~cm}$ with a standard deviation of $12 \mathrm{~cm}$. The one-way ANOVA statistical test resulted in no statistical difference $(p>0.05)$ for the mean depth within the different soil series.

\subsection{Depth to clay under watershed context}

We compared the depth to Bt and watershed size (Fig. 9) with the assumption that more sediment could accumulate within wetland footprints that have larger watersheds. Yet, the oneway ANOVA statistical test results did not indicate any significant differences $(p>0.05)$ in the thickness of accumulated soils above the $\mathrm{Bt}$ by watershed sizes. For the 63 sampling points in the smaller watersheds (area $<0.40 \mathrm{~km}^{2}$ ), the mean thickness of accumulated soils above the $\mathrm{Bt}$ was found at $40 \mathrm{~cm}$ with a standard deviation of $11 \mathrm{~cm}$. For the $156 \mathrm{sam}-$ pling points in the medium-small watersheds (area between 0.41 and $2.02 \mathrm{~km}^{2}$ ), the mean thickness of accumulated soils above the Bt was found at $39 \mathrm{~cm}$ with a standard deviation of $11 \mathrm{~cm}$. For the 36 sampling points in the medium-large watersheds (area between 2.03 and $4.05 \mathrm{~km}^{2}$ ), the mean 
Fig. 6 The variability in depth to Bt across all publicly managed wetlands sampled by using the EMI method

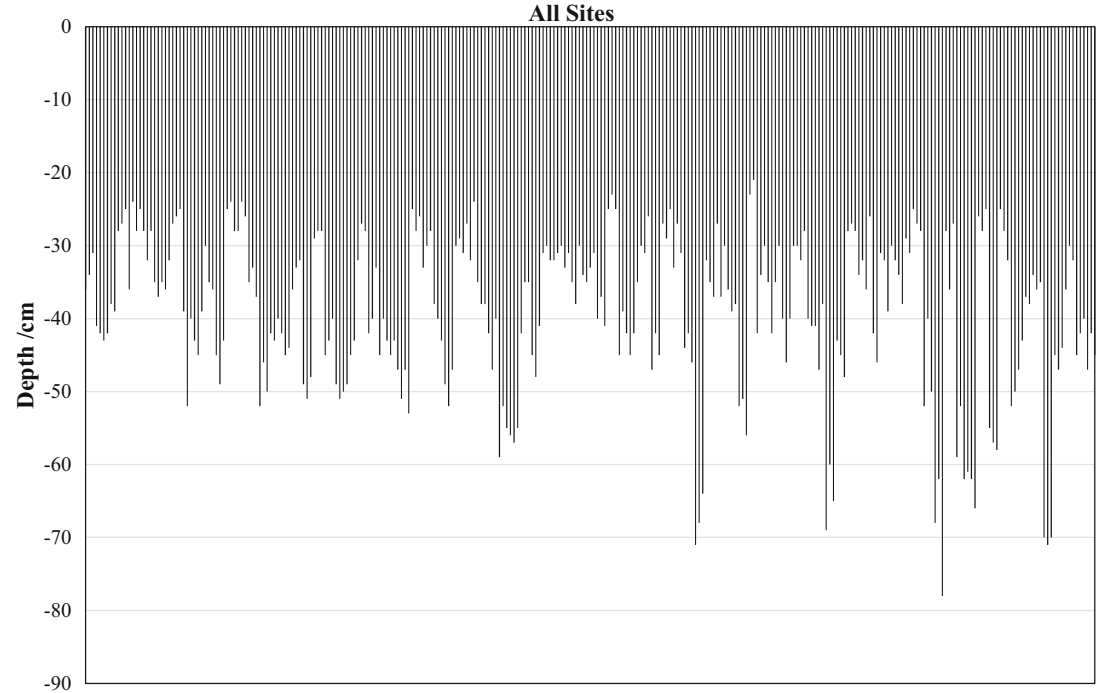

thickness of accumulated soils above the Bt was found at $38 \mathrm{~cm}$ with a standard deviation of $10 \mathrm{~cm}$. For the 24 sampling points in the large watersheds (area above $2.03 \mathrm{~km}^{2}$ ), the mean thickness of accumulated soils above the $\mathrm{Bt}$ was found at $41 \mathrm{~cm}$ with a standard deviation of $10 \mathrm{~cm}$.

We also evaluated watershed slope and the accumulation of soils above the $\mathrm{Bt}$ in these wetlands (Fig. 10). For the 66 sampling points in watersheds with a slope above $10^{\circ}$, the mean thickness of accumulated soils above the Bt reached $45 \mathrm{~cm}$ with a standard deviation of $12 \mathrm{~cm}$. For the 99 sampling points in the watersheds with slopes of $5-10^{\circ}$, the mean thickness of accumulated soils above the Bt was $38 \mathrm{~cm}$ with a standard deviation of $11 \mathrm{~cm}$. For the 114 sampling points in the watersheds with slopes less than $5^{\circ}$, the mean thickness of accumulated soils above the Bt was $37 \mathrm{~cm}$ with a standard deviation of $7 \mathrm{~cm}$.

\section{Discussion}

\subsection{Sediment accumulation rate}

The thickness of soils, presumably the accumulations of organic matter and sediment deposited through fluvial and eolian processes, accumulated above the Bt horizon in each playa wetland represented the sediments in association with entire corresponding watershed. Soils originating from higher lands have been transported to the lowest areas in these hydrologically closed watersheds. We selected sample

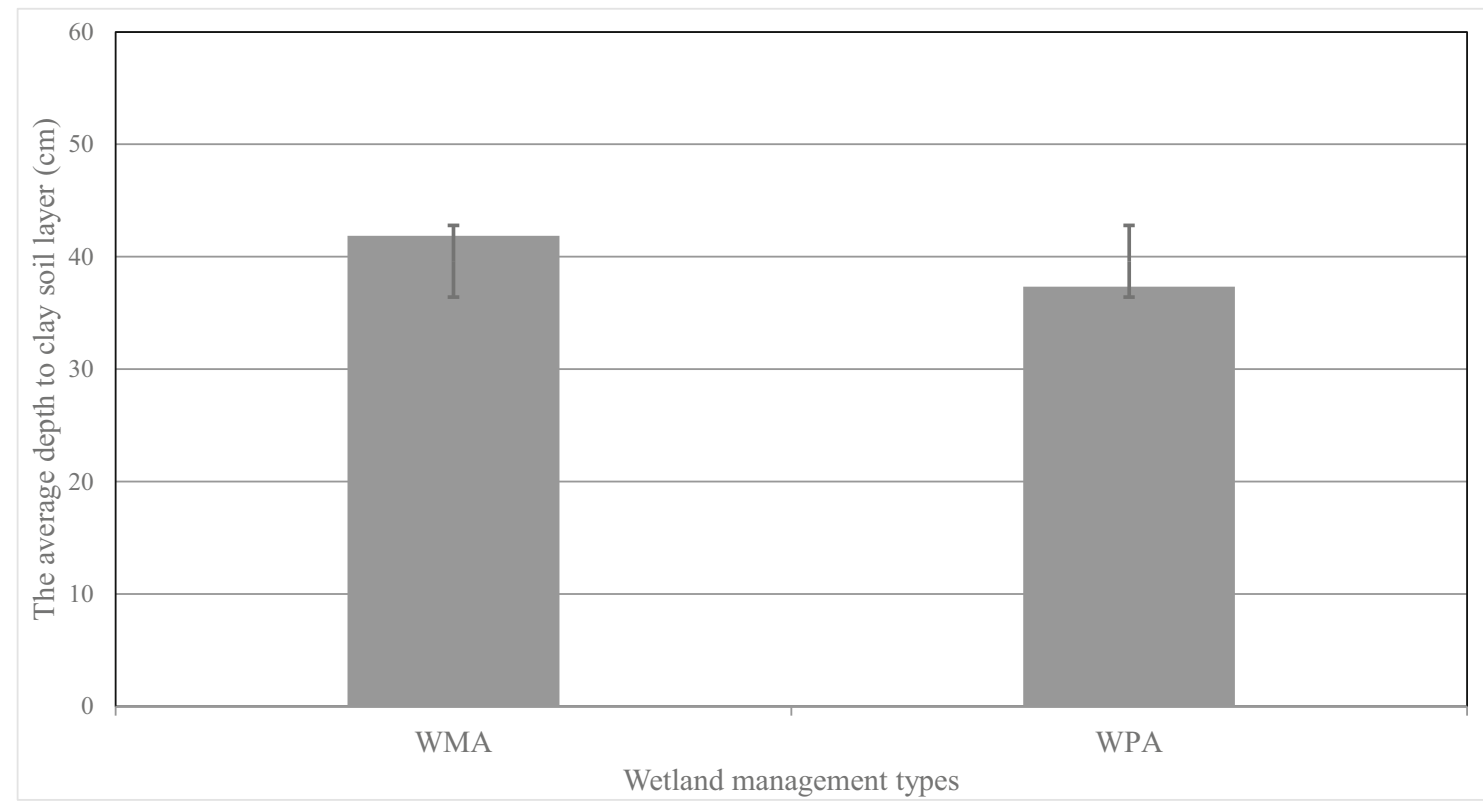

Fig. 7 The mean depth to the Bt horizon between State WMA and Federal WPA wetlands 


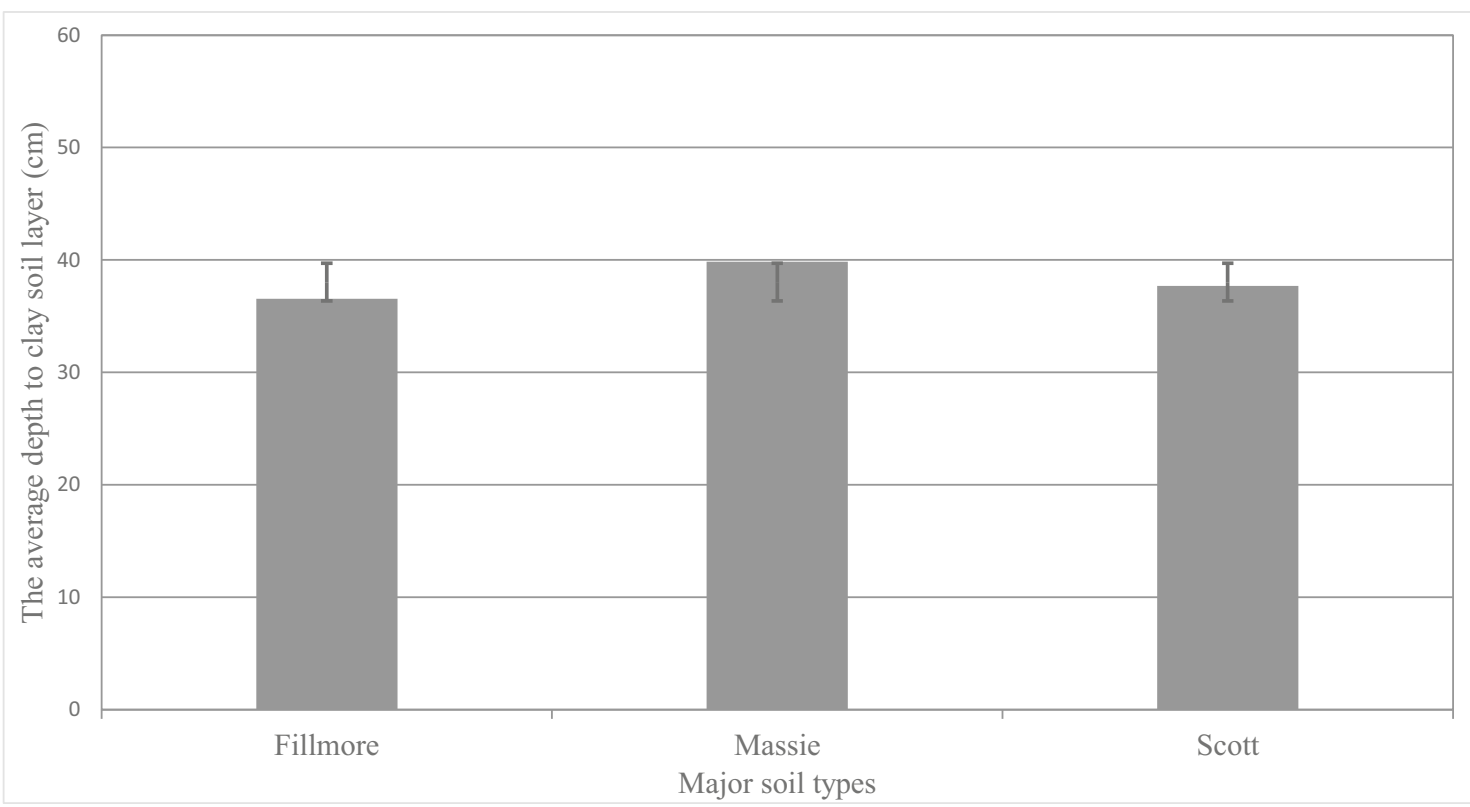

Fig. 8 The mean depth to Bt for the major hydric footprint soil types

locations at the lowest points within hydric soil footprints that were distal from watershed delivery points to avoid sampling in areas with excessive accumulations. We found that wetlands within the Rainwater Basin had similar sediment accumulation ranges in the High Plains playa wetlands. O'Connell et al. (2013) found that High Plain playa wetlands with either native grasslands or croplands had depth to the $\mathrm{Bt}$ horizon ranging from 1.0 to $78.0 \mathrm{~cm}$. Based on our inversion analysis results and assuming no accumulation of soils above the $\mathrm{Bt}$ in some wetlands as indicated by Layton et al. (1927), the annual post-settlement sediment accumulation rates $(0.14$ $0.52 \mathrm{~cm} \mathrm{year}^{-1}$ ) were similar to the $0.18-0.29 \mathrm{~cm} \mathrm{year}^{-1}$ in five playa wetland sites found by Tang et al. (2015a) and were also similar to the mean of $0.34 \mathrm{~cm}_{\text {year }}{ }^{-1}$ found by Jones and Olson (1990).

The results of this study also showed that soils accumulated above the Bt horizon have been increased during the past century. Even though considerable variations existed, it is apparent that the depth to $\mathrm{Bt}$ is increasing based on the earliest documented soil conditions in contrast with contemporary soil conditions in Rainwater Basin wetlands. The available depth to Bt in the early Nebraska soil survey between 1919 and 1934 (Layton et al. 1927; and summarized in LaGrange et al. 2011), in the wetland soil surveys during 1997-2009 in the SSURGO

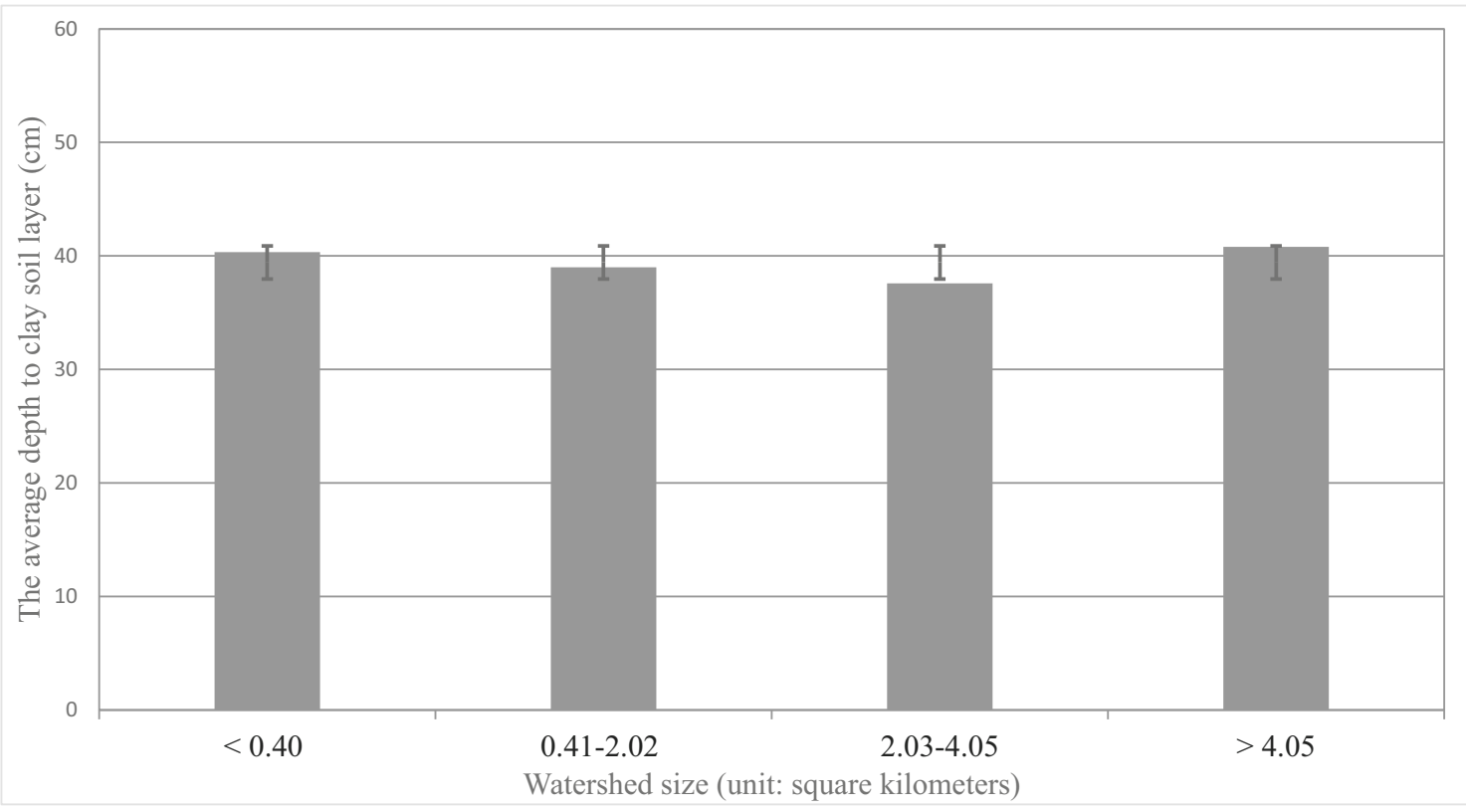

Fig. 9 The mean depth to the Bt horizon for wetlands within four watershed size categories 


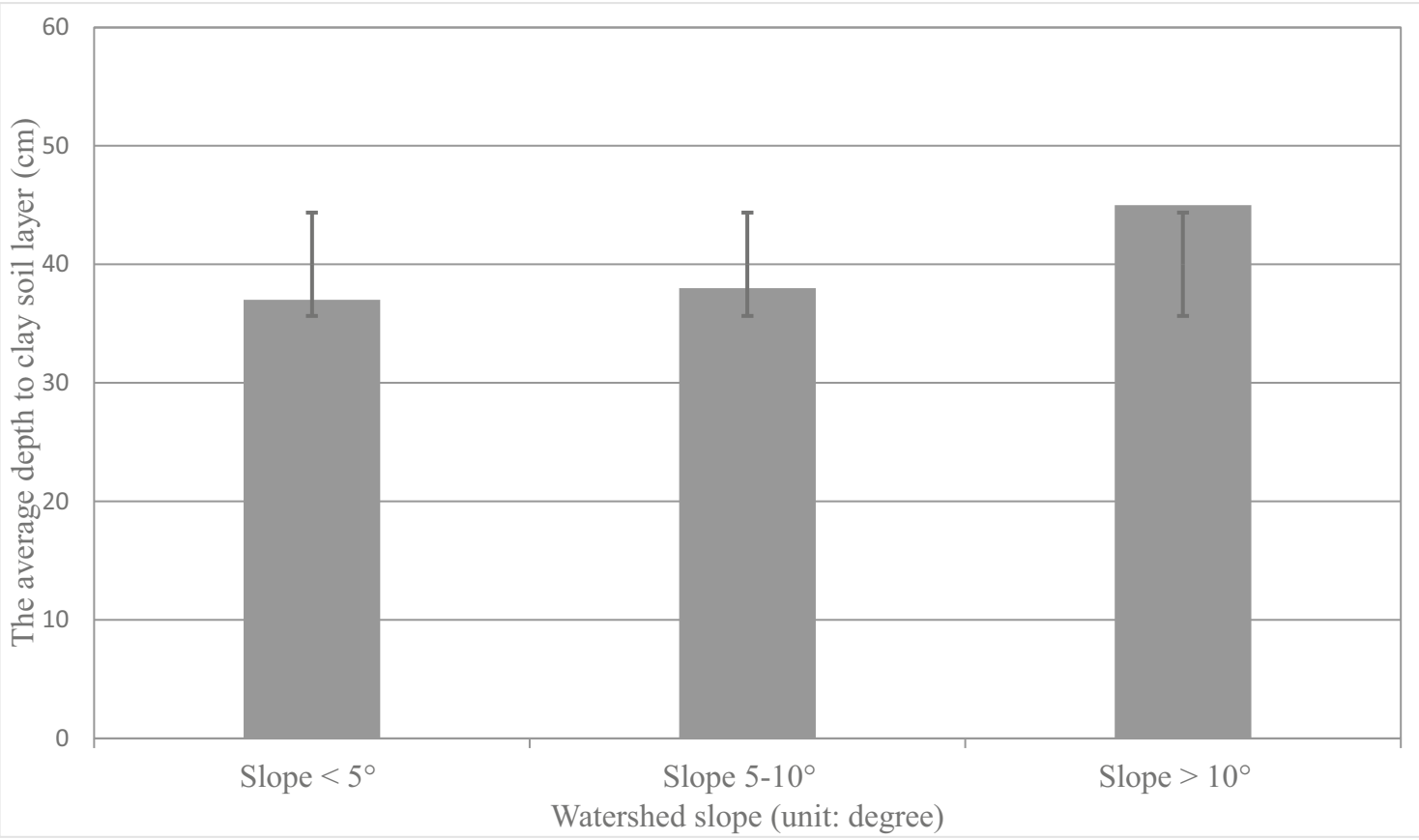

Fig. 10 The mean depth to the Bt horizon for three watershed slope categories that provide the primary source of runoff water to the wetland

data (NRCS 2015), and our EMI measurements in 2016 indicated a consistent progression of soil accumulation above the Bt. The mean depth to the contemporary Bt horizon has increased from the earliest documented soil conditions (19161934) because culturally accelerated sedimentation related to human activities that facilitated rapid soil movement into playa wetlands, yet these reference conditions are 50-70 years after many of these lands were first plowed. In early soil surveys published from 1916 to 1934, the depth to Bt for Fillmore soils had a range of 15-38 cm, and Scott soils had a range of 13-30 cm (LaGrange et al. 2011). The first soil survey did not describe a Massie soil series so these areas were classified into the Scott soils series. Although the sample size and locations were different between the SSURGO surveys and the EMI surveys, similar trends were observed in increased sediment accumulation among the playa wetlands. In the 1990s-2000s field soil survey results for playa wetlands in the Rainwater Basin, the depth to Bt in Fillmore soils had a sediment thickness range of 28-74 cm (our EMI result: 24 $66 \mathrm{~cm}$ ), Scott soils had a sediment thickness range of 8-23 cm (our EMI result: $24-66 \mathrm{~cm}$ ), and the Massie soils had a sediment thickness range of 10-64 cm (our EMI result: 23-78 cm). Additionally, the sampling locations from the first soil surveys were likely different, but the increased soil thickness above the Bt in current playa soils is apparent. These early soil surveys within Rainwater Basin counties indicate the depth to $\mathrm{Bt}$ in Fillmore soils ranging from $15-38 \mathrm{~cm}$ and ranging from $2.5-64 \mathrm{~cm}$ in Scott soils (NRCS 2019).

The variations in the thickness of culturally accelerated sediment above the clay were a result of environmental influences associated with deposition and deflation events. The variability of culturally accelerated sedimentation actually reflects a series of complex hydrologic and climatic processes such as hydrological alteration, conservation practices within each watershed, eolian processes (both deposition and deflation), the grid road system, variations in topography that have occurred since settlement, and vegetative conditions that can add organic matter over time.

The rate of culturally accelerated sedimentation has not been physically measured but has been projected for Rainwater Basin wetlands. Yet, some studies have identified factors that directly influence accumulation rates such as climate conditions, soil types, wetland and watershed size, and land use types within the watershed (Tsai et al. 2007; Novotny 2008; O'Connell et al. 2013; Tang et al. 2015b). Among those factors, the variations in microtopography in combination with the human-made hydrologic alterations at watershed scale are all important roles in effecting sediment accumulation in wetlands. For example, roads cut off the pathway for natural runoff conveyance into wetlands, and concentration pits collect and store large volumes of water that would otherwise flow into wetlands. Both man-made features and agricultural infrastructure have wholly changed watersheds in the Rainwater Basin, and thus changed the patterns of sediment inputs into wetlands. Additionally, the upper soil horizon in many wetlands has been mixed by either hoof action as a result of wetland grazing or other management techniques such as discing or rototilling in wetlands (Tang et al. 2015a). In terms of micro-level topographic variations, wind erosion can naturally create different patterns of soil deposition including sediment dunes within wetlands that can also 
influence local sediment accumulation rates and can alter water movement patterns within the wetlands (LaGrange et al. 2011). During extended dry periods and drought years, Rainwater Basin wetlands can develop deep desecration cracks at the soil surface (Wilson 2010). The deep cracks in combination with the deep vegetative tap roots during droughts (Lindh et al. 2014) can contribute to creating conduits that facilitate downward water movement (Wilson 2010), and at times can even create visible vortices and therefore could initiate downward sediment movement. All of these factors can create high variability in sediment accumulation patterns within Rainwater Basin wetlands.

\subsection{Policy implications for wetland conservation and restoration practices}

To slow down the culturally accelerated sedimentation process, federal conservation programs have implemented practices such as the use of cover crops, no-till farming, and restoration of portions of watersheds from cultivated croplands to native grasslands in targeted areas (e.g., steeper slopes, water ways) across the Rainwater Basin area (Tsai et al. 2007; Cariveau et al. 2011). Establishing vegetative buffer strips along wetlands has been widely recognized as a simple, effective, and inexpensive conservation practice that can reduce sediment deposition in playa wetlands (Chaubey et al. 1994; Gleason 1996; Beas et al. 2013b; Smith et al. 2014; Tang et al. 2015b). If conservation programs focus on implementing practices that reduce the rate and amount of sediment delivered to wetlands, managers could then expect longer sustainability in a desirable condition after within-basin sediment removal restoration work has been completed. Therefore, these practices could also reduce the amount of water delivered to the wetland and therefore future research is needed to determine how wetland function is influenced by each practice considered.

Selecting cost-effective restoration practices can be challenging when faced with significantly altered habitats that provide limited ecosystem services, particularly when funds are limited (Adame et al. 2014). Sediment removal is recognized as a direct and effective way to restore wetlands impacted by the culturally accelerated sedimentation, and this treatment can increase ponded area, ponded volume, and average ponded depth in wetlands (Luo et al. 1997; Tsai et al. 2007; Cariveau et al. 2011). However, over-excavation can also remove portions of the clay soil layer and increase the potential of downward transmissivity, and thus pose unnecessary threats on the bio-geochemical and hydrological functions of wetlands. Therefore, it is important to precisely determine the depth to the clay soil layer before implementing any sediment removal restoration projects to reduce the risk of removing any of the Bt horizon.

\section{Conclusions}

This study demonstrated the utility of using the EMI technique to determine the depth to $\mathrm{Bt}$ for hydric soils and therefore the culturally accelerated sediment thickness in playa wetlands. Our research findings confirmed that the EMI technique is effective and efficient in determining the amount soil above the $\mathrm{Bt}$ horizon. The depth to $\mathrm{Bt}$ measurement provided important vertical profile information that can help characterize the spatial variability of soil deposition in playa wetlands. The detected sediment thickness values provided important scientific data that will help guide future wetland restoration projects that include sediment removal. The depth to Bt reflects the contemporary hydrologic capacity in playa wetlands. Our results provided an overall summary of contemporary sediment accumulations in all publicly managed wetlands. Essentially, compared with 1920s soil surveys, the increased soil thickness above the $\mathrm{Bt}$ in playa wetlands clearly demonstrated the impacts of human activities during the past century that have accelerated soil accumulation rates. The sediment thickness profiles highlighted the continuous long-term challenge of sediment management efforts for playa wetlands within agricultural landscapes.

Compared with the traditional methods used to determine the depth to $\mathrm{Bt}$, such as soil cores, fly ash, and pollen analysis, this alternative method is rapid (with 10-15 min for each sampling point), simple (with standard operation manual), non-invasive (no need for machine or truck for soil core drilling), cost-effective (with the investment of the equipment and software cost for approximately US\$20,000-30,000), and reusable (one machine for long-term use), and it requires only basic knowledge in geophysical and soil science. However, the geophysical interpretations can only be used as preliminary evaluations of site conditions. Remote and general site investigations (e.g., SSURGO soil review) are interpretive results that cannot be used as a replacement for direct ground-truth observations for each wetland. The use of the EMI technique could reduce the number of soil core observations needed, and therefore supplement the ground-truth soil profile observation and interpretation.

At the same time, we need to recognize the limitations of EMI methods. For example, the sediment thickness itself could be subject to many factors, including micro-elevation, on-site hydrological conditions, vegetation coverage, wetland size, watershed characteristics, climate conditions, and human activities. The EMI measurement could be effected by other operational or contextual variables, such as temperature, water table, salinity, and water quality conditions (e.g., total dissolved solids, salts, and minerals). There are also field limitations for using the EMI method in wetlands. It was extremely difficult to gain access to all parts of many wetlands because of ponding and/or extremely dense and tall vegetation. These conditions would create additional challenges if transects are 
needed for a full grid-type evaluation which might be needed when comprehensive restoration plans are desired. Thus, the practical application for continuous mobilized mapping using EM38-MK2 for the large wetland areas may be limited by site conditions. Therefore, data collection to represent the general sedimentation accumulation conditions of whole wetlands can only be made in the accessible hydric soil areas or when conditions are ideal such as after prescribed fire. Yet, this may prevent seasonal opportunities when environmental and habitat conditions facilitate efficient data collection. Furthermore, experimental random error is unavoidable in terms of the certain height of equipment above the ground because of the variations in micro-topography in wetlands in combination with the unsteadiness when elevating and holding the equipment by hand. In addition, the sampling locations also influence the representativeness of sediment thickness throughout certain wetlands. In particular, the road systems and culvert placement have significantly changed the natural hydrologic connectivity that is critical to playa wetland function in the Rainwater Basin.

The results of this study indicate that significant amounts of soil have accumulated above the Bt horizon in all 93 publicly managed playa wetlands in the Rainwater Basin area. Additionally, considerable variations in the depth to $\mathrm{Bt}$, presumably recent sediment accumulation, were detected across all wetlands. This research indicates that it is possible to conduct a transect survey that would provide a detailed sediment profile to help visualize soil conditions at the wetland scale. Future wetland restoration designs should include careful evaluation of watershed features and within-basin factors that influence each wetland's hydrologic capacity such as the amount of organic matter within soil that has accumulated above the Bt layer. We recommend that the sediment profile of any wetland targeted for restoration be examined to determine the depth to Bt to help identify the amount of soil that could be removed to increase sustainability and wetland function and to maximize ponding frequency while also determining the maximum depth of removal to avoid removing the high clay content soils within the Bt horizon.

Acknowledgments The research team sincerely appreciates the valuable guidance, field survey support, and data sharing support from the U.S. Fish and Wildlife Service, the U.S. Department of Agriculture-Natural Resources Conservation Service, the Rainwater Basin Joint Venture, and the Nebraska Game and Parks Commission. We also appreciate the valuable suggestions and constructive comments from the three reviewers and the editors.

Funding information This paper has been funded by the United States Environmental Protection Agency (EPA) under assistance agreement (CD 97753701).

\section{Compliance with ethical standards}

Conflict of interest The contents do not necessarily reflect the views and policies of the funding agencies, and do not mention the trade names or commercial products that constitute endorsement or recommendation for use. The findings and conclusions in this paper are those of the authors and do not necessarily represent the views of the U.S. Fish and Wildlife Service.

\section{References}

Adame MF, Hermoso V, Perhans K, Lovelock CE, Herrera-Silveira JA (2014) Selecting cost-effective areas for restoration of ecosystem services. Conserv Biol 29:493-502

Allen BL, Harris BL, Davis KR, Miller GB (1972) The mineralogy and chemistry of High Plains playa lake soils sediments. Texas Tech University Water Resources Center, Lubbock

Ammons JT, Timpson ME, Newton DL (1989) Application of an aboveground electromagnetic conductivity meter to separate Natraqalfs and Ochraqualfs in Gibson County, Tennessee. Soil Surv Horiz 30:66-70

Beas BJ, Smith LM, LaGrange TG, Stutheit R (2013a) Effects of sediment removal on vegetation communities in Rainwater Basin playa wetlands. J Environ Manag 128:371-379

Beas BJ, Smith LM, Hickman KR, LaGrange TG, Stutheit R (2013b) Seed bank responses to wetland restoration: do restored wetlands resemble reference wetland conditions following sediment removal? Aquat Bot 108:7-15

Boettinger JL, Doolittle JA, West NE, Bork EW, Schupp EW (1997) Non-destructive assessments of rangeland soil depth using electromagnetic induction. Arid Soil Res Rehabil 11:375-390

Borchers B, Uram T, Hendrickx JM (1997) Tikhonov regularization of electrical conductivity depth profiles in field soils. Soil Sci Soc Am J 61:1004-1009

Bork EW, West NE, Doolittle JA, Boettinger JL (1998) Soil depth assessment of sagebrush grazing treatments using electromagnetic induction. J Range Manag 51:469-474

Brennan EK, Smith LM, Haukos DA, LaGrange TG (2005) Short-term response of wetland birds to prescribed burning in Rainwater Basin wetlands. Wetlands 25:667-674

Cariveau AB, Pavlacky DC Jr, Bishop AA, LaGrange TG (2011) Effects of surrounding land use on playa inundation following intense rainfall. Wetlands 31:65-73

Chaubey I, Edwards DR, Daniel TC, Moore PA, Nichols DJ (1994) Effectiveness of vegetative filter strips in retaining surface-applied swine manure constituents. Trans ASAE 37:845-850

Cook PG, Walker GR (1992) Depth profiles of electrical conductivity from linear combinations of electromagnetic induction measurements. Soil Sci Soc Am J 56:1015-1022

Corwin DL, Lesch SM (2005) Apparent soil electrical conductivity measurements in agriculture. Comput Electron Agric 46:11-43

Cowardin LM, Carter V, Golet FC, LaRoe ET (1979) Classification of wetlands and deepwater habitats of the United States. U.S. Department of the Interior, Fish and Wildlife Service, Washington, D.C. Jamestown, ND: Northern Prairie Wildlife Research Center Online. http://www.npwrc.usgs.gov/resource/wetlands/classwet/ index.htm. Accessed 03/01/2017

Daniel DW, Smith LM, McMurry ST (2015) Land use effects on sedimentation and water storage volume in playas of the Rainwater Basin of Nebraska. Land Use Policy 42:426-431

Daniel DW, Smith LM, TcMurry ST (2017) Effects of sediment removal and surrounding land use on carbon and nitrogen storage in playas and watersheds in the Rainwater Basin region of Nebraska. Soil Tillage Res 174:169-176

de Jong E, Ballantyne AK, Cameron DR, Read DL (1979) Measurement of apparent electrical conductivity of soils by an electromagnetic induction probe to aid salinity surveys. Soil Sci Soc Am J 43:810 812 
Doolittle JA, Brevik EC (2014) The use of electromagnetic induction techniques in soils studies. Geoderma 223-225:33-45

Doolittle JA, Sudduth KA, Kitchen NR, Indorante SJ (1994) Estimating depth to claypans using electromagnetic inductive methods. J Soil Water Conserv 49:552-555

Doolittle JA, Indorante SJ, Kremel P, Grantham DR, Berning BV (1995) Mapping the thickness of flood-plain splay deposits with electromagnetic induction. Soil Surv Horiz 36:59-67

Drahota J, Reichart LM (2015) Estimating seed availability for annual and perennial emergent plant communities in the rainwater basin. Wetlands 35:1105-1116

Freeland RS (1989) Review of soil moisture sensing methods using soil electrical conductivity. Trans ASAE 32:2190-2194

Freeland RS, Branson JL, Ammons JT, Leonard LL (2001) Surveying perched water on anthropogenic soils using non-intrusive imagery. Trans ASAE 44:1955-1963

Galatowitsch SM, Anderson NO, Ascher PA (1999) Invasiveness in wetland plants of temperate North America. Wetlands 19:733-755

Gebbers R, Lück E, Heil K (2007) Depth sounding with the EM38detection of soil layering by inversion of apparent electrical conductivity measurements. Precis Agric 7:95-102

Gersib RA, Dinan KF, Kauffeld JD, Onnen MD, Gabig PJ, Cornely JE, Jasmer GE, Hyland JM, Strom KJ (1992) An implementation plan for the rainwater basin joint venture. Nebraska Game and Parks Commission, Lincoln $56 \mathrm{pp}$

Gill TE (1996) Eolian sediments generated by anthropogenic disturbance of playas: human impacts on the geomorphic system and geomorphic impacts on the human system. Geomorphology 17:207-228

Gleason RA (1996) Influence of agricultural practices on sedimentation rates, aquatic invertebrates, and bird-use in prairie wetlands. Humboldt State University, Arcata

Gleason RA, Euliss NH Jr (1998) Sedimentation of prairie wetlands. Great Plains Res 8:97-112

Goldsborough LG, Crumpton WG (1998) Distribution and environmental fate of pesticides in prairie wetlands. Great Plains Res 8:73-95

Grisso RD, Alley MM, Holshouser DL, Thomason WE (2009) Precision farming tools: soil electrical conductivity. Virginia Cooperative Extension 442:1-6. https:/vtechworks.lib.vt.edu/bitstream/handle/ 10919/51377/442-508.pdf? sequence $=1 \&$ isAllowed $=y$. Accessed 03/01/2017

Haukos DA, Smith LM (2003) Past and future impacts of wetland regulations on playa ecology in the Southern Great Plains. Wetlands 23: $577-589$

Heil K, Schmidhalter U (2012) Characterisation of soil texture variability using apparent electrical conductivity at a highly variable site. Comput Geosci 39:98-110

Herrero J, Castaneda C (2015) Temporal changes in soil salinity at four saline wetlands in NE Spain. Catena 133:145-156

Hezarjaribi A, Sourell H (2007) Feasibility study of monitoring the total available water content using non-invasive electromagnetic induction-based and electrode-based soil electrical conductivity measurements. Irrig Drain 56:53-65

Huth NI, Poulton PL (2007) An electromagnetic induction method for monitoring variations in soil moisture in agroforestry systems. Aust J Soil Res 45:6372

Jones RL, Olson KR (1990) Fly ash use as a time marker in sedimentation studies. Soil Sci Soc Am J 54:855-859

Kitchen NR, Sudduth KA, Drummond ST (1996) Mapping of sand deposition from 1993 Midwest floods with electromagnetic induction measurements. J Soil Water Conserv 51:336-340

Kuzila MS, Lewis DT (1993) Properties and genesis of loessial soils across a south-central Nebraska basin. Soil Sci Soc Am J 57:155161

LaGrange T (2005) A guide to Nebraska's wetlands and their conservation needs (Second Edition). Nebraska Game and Parks Commission, Lincoln, p 59
LaGrange TG, Stutheit R, Gilbert M, Shurtliff D, Whited PM (2011) Sedimentation of Nebraska's playa wetlands: a review of current knowledge and issues. Nebraska Game and Parks Commission, Lincoln, p 62

Layton MH, Huddleston AN, Condra GE, Hayes FA (1927) Soil Survey of Kearney County, Nebraska. U.S. Department of Agriculture Bureau of Soils, Washington Government Printing Office, pp 441484

Lindh M, Zhang L, Falster D, Franklin O, Brannstrom A (2014) Plant diversity and drought: the role of deep roots. Ecol Model 290:85-93

Luo AH, Smith LM, Allen BL, Haukos DA (1997) Effects of sedimentation on playa wetland volume. Ecol Appl 7:247-252

Luo HR, Smith LM, Haukos DA, Allen BL (1999) Sources of recently deposited sediments in playa wetlands. Wetlands 19:176-181

McNeill JD (1980) Electrical conductivity of soils and rocks (Geonics Ltd., Mississauga, Ontario, Canada, Technical Note TN-5)

Natural Resources Conservation Service (NRCS) (2002) SOIGeophysical field assistance, Natural Resources Conservation Service, United States Department of Agriculture, Wilkesboro, NC, 28697. November 12, 2002

Natural Resources Conservation Service (NRCS) (2015) Soil Survey Geographic (SSURGO) database. U.S. Department of Agriculture, Fort Worth https://websoilsurvey.nrcs.usda.gov/app/ WebSoilSurvey.aspx. Accessed 06/01/2016

Natural Resources Conservation Service (NRCS) (2019) Published Soil Surveys for Nebraska database. U.S. Department of Agriculture, Fort Worth https://www.nrcs.usda.gov/wps/portal/nrcs/surveylist/ soils/survey/state/?stateId=NE. Accessed 01/15/2019

Novotny CW (2008) Fly ash in sediments as a marker to estimate preagricultural bathymetry of glaciated prairie wetlands. Master Thesis, South Dakota State University, Brookings, South Dakota

O'Connell JL, Johnson LA, Daniel DW, McMurry ST, Smith LM, Haukos DA (2013) Effects of agricultural tillage and sediment accumulation on emergent plant communities in playa wetlands of the US High Plains. J Environ Manag 120:10-17

Olson BKR, Jones RL (2001) Use of fly ash as time marker in soil erosion and sedimentation studies. Sustaining the Global Farm, pp 10591061

Potter LA, Schamel W (1997) The Homestead Act of 1862. Soc Educ 61: 359-364

Renard KG, Foster GR, Weesies GA, McCool DK, Yoder DC (1997) Predicting soil erosion by water: a guide to conservation planning with the Revised Universal Soil Loss Equation (RUSLE) (Vol. 703). US Government Printing Office, Washington, DC

Rhoades JD, Manteghi NA, Shouse PJ, Alves WJ (1989) Soil electrical conductivity and soil salinity: new formulations and calibrations. Soil Sci Soc Am J 53(2):433-439

Saey T, Simpson D, Vitharana UWA, Vermeersch H, Vermang J, Van Meirvenne M (2008) Reconstructing the paleotopography beneath the loess cover with the aid of electromagnetic induction sensors. Catena 74:58-64

Saey T, Simpson D, Vermeersch H, Cockx L, Van Meirvenne M (2009) Comparing the EM38DD and DUALEM-21S sensors for depth-toclay mapping. Soil Sci Soc Am J 73:1-12

Schafersman S (2011) Geology of the playas and Ogallala aquifer of the Llano Estacado. www.llanoestacado.org/resources/geology_playas ogallala.pdf. Accessed on 1 Jan 2017

Smith LM (2003) Playas of the Great Plains. University of Texas Press, Austin

Smith LM, Haukos DA (2002) Floral diversity in relation to playa wetland area and watershed disturbance. Conserv Biol 16:964-974

Smith TE, Kolka RK, Zhou X, Helmers MJ, Cruse RM, Tomer MD (2014) Effects of native perennial vegetation buffer strips on dissolved organic carbon in surface runoff from an agricultural landscape. Biogeochemistry 120(1-3):121-132 
Sudduth KA, Kitchen NR, Hughes DH, Drummond ST (1995) Electromagnetic induction sensing as an indicator of productivity on claypan soils. In: Robert PC, Rust RH, Larson WE (eds) Proceedings of Second International Conference on Precision Management for Agricultural Systems. March 27-30, 1994, Minneapolis, Minnesota. American Society of Agronomy, Madison, Wisconsin, pp 671-681

Sudduth KA, Kitchen NR, Drummond ST (1999) Soil conductivity sensing on claypan soils: comparison of electromagnetic induction and direct methods. Proc $4^{\text {th }}$ Int Conf on Precision Agriculture pp 979990. ASA, CSSA, and SSSA, Madison, WI. USA.

Sudduth KA, Kitchen NR, Myers DB, Drummond ST (2010) Mapping depth to argillic soil horizons using apparent electrical conductivity. J Environ Eng Geophys 15:135-146

Sundberg K (1932) Effect of impregnating waters on electrical conductivity of soils and rocks. Trans Soc Min Metall 97:367-391

Tang Z, Gu Y, Drahota J, LaGrange T, Bishop A, Kuzila MS (2015a) Using fly ash as a marker to quantify culturally-accelerated sediment accumulation in playa wetlands. J Am Water Resour Assoc 51: $1643-1655$

Tang Z, Gu Y, Dai Z, Li Y, LaGrange T, Bishop A, Drahota J (2015b) Examining playa wetland inundation conditions for National Wetland Inventory, Soil Survey Geographic database, and LiDAR data. Wetlands 35:641-654

Tang Z, Li Y, Gu Y, Jiang W, Xue Y, Hu Q, LaGrange T, Bishop A, Drahota J, Li R (2016) Assessing Nebraska playa wetland inundation status during 1985-2015 using Landsat data and Google Earth Engine. Environ Monit Assess 188:654

Tang Z, Drahota J, Hu Q, Jiang W (2018) Examining playa wetland contemporary conditions in the Rainwater Basin, Nebraska. Wetlands 38:25-36
Tsai JS, Venne LS, McMurry ST, Smith LM (2007) Influences of land use and wetland characteristics on water loss rates and hydroperiods of playas in the Southern High Plains, USA. Wetlands 27:683-692

Tsai JS, Venne LS, McMurry ST, Smith LM (2010) Vegetation and land use impact on water loss rate in playas of the Southern High Plains, USA. Wetlands 30:1107-1116

Uden DR, Allen CR, Bishop AA, Grosse R, Jorgensen CF, LaGrange TA, Stutheit R, Vrtiska MP (2015) Predictions of future ephemeral springtime waterbird stopover habitat availability under global change. Ecosphere 6:1-26

USFWS (2007) Rainwater basin wetland management district Comprehensive Conservation Plan (CCP). U.S. Department of the Interior, Fish and Wildlife Service, Funk, p 198

White ML, Shaw JN, Raper RL, Rodekohr D, Wood CW (2012) A multivariate approach for high-resolution soil survey development. Soil Sci 177:345-354

Williams BG, Baker GC (1982) An electromagnetic induction technique for reconnaissance surveys of soil salinity hazards. Aust J Soil Res 20:107-118

Wilson RD (2010) Evaluating hydroperiod response in the rainwater basin wetlands of south-central Nebraska. M.S. Thesis, University of Nebraska-Lincoln, $163 \mathrm{pp}$

Yao RJ, Yang JS, Zhao XF, Chen XB, Han JJ, Li XM, Liu MX, Shao HB (2012) A new soil sampling design in coastal saline region using EM38 and VQT method. Clean-Soil Air Water 40:972-979

Publisher's note Springer Nature remains neutral with regard to jurisdictional claims in published maps and institutional affiliations. 